\title{
Do ESOPs enhance firm performance? Evidence from China's reform experiment
}

\author{
Rujing Meng ${ }^{\mathrm{a}}$, Xiangdong Ning ${ }^{\mathrm{b}}$, Xianming Zhou ${ }^{\mathrm{c}, *}$, and Hongquan Zhu ${ }^{\mathrm{d}}$ \\ ${ }^{a}$ University of Hong Kong \\ ${ }^{\mathrm{b}}$ Tsinghua University \\ ${ }^{\mathrm{c}}$ University of Hong Kong \\ ${ }^{\mathrm{d}}$ Southwest Jiaotong University
}

October 30,2010

\begin{abstract}
China introduced employee stock ownership plans (ESOPs) in 1992 purely as an employee incentive scheme. The government initiated the policy experiment on ESOPs as part of China's reform of its state-owned enterprises, and it was abruptly terminated two years after initiation. This policy experiment resulted in an exogenous sample of ESOPs that allows us to provide the first evidence from Chinese firms on the performance-ESOP relation. After examining a variety of performance measures, including ROA, ROE, Tobin's q, and productivity, we find little difference in performance between ESOP firms and non-ESOP firms.
\end{abstract}

JEL classification: G32; J32

Keywords: Employee ownership; Incentives; Firm performance

* Corresponding author. Tel.: +852 2857 8564; Fax: +852 25481152.

E-mail addresses: meng@hku.hk (R. Meng), ningxd@sem.tsinghua.edu.cn (X. Ning), xianming.zhou@hku.hk (X. Zhou),hqzhu@home.swjtu.edu.cn (H. Zhu).

\footnotetext{
${ }^{\square}$ We thank an anonymous referee for many helpful suggestions. Meng and Zhou acknowledge financial support from Hong Kong Research Grants Council (Competitive Earmarked Research Grant Awards 1048/02H) and HKU Strategic Research Theme in China Business and Economics. Ning thanks the National Natural Science Foundation of China (\#70672002) for financial support. Yao Huang provided valuable research assistance.
} 


\section{Introduction}

In this paper, we use a unique sample of listed Chinese firms to examine the impact of employee stock ownership plans (ESOPs) on corporate performance. Unlike widely examined U.S. plans, the Chinese ESOP resulted from a policy experiment that started in 1992. Before that time, China's predominantly state-owned enterprises (SOEs) did not allow employee ownership. In 1992, the Chinese government took dramatic action by starting the process of corporatization, in which SOEs were allowed to be privatized through share ownership and become an incorporated company. When SOEs became a corporation, they were allowed to adopt an ESOP with the approval of regulatory authorities. This trial policy was terminated two years later when the government abruptly stopped approving new applications for ESOPs. Because the policy applied to all incorporated firms and its timing (from the start to the end) was exogenous to individual firms, this policy experiment provides us with an exogenous sample of Chinese ESOPs.

ESOPs are typically used as a pension plan, as in the U.S., by linking employees' retirement wealth to the long-run performance of the company's stock. It is argued that by aligning the interests of employees and shareholders, ESOPs provide incentives for employees to increase their effort in production, thus enhancing company performance. Previous studies have examined the effect of ESOP adoption using Japanese, Korean, and U.S. data and have obtained mixed results. Consistent with the tax-saving benefit of ESOPs in the U.S., Gordon and Pound (1990) and Beatty (1995) document positive announcement and adoption effects. However, the effect on the post-adoption performance, which is indicative of employee incentives, is ambiguous. Kumbhakar and Dunbar (1993), Jones and Kato (1995), and Cin and Smith (2002) report higher post-adoption productivity for ESOP firms, while others, including U.S. GAO (1987) and Conte 
et al. (1996), do not find a clear, positive effect of ESOPs on performance. Indeed, Conte et al. find that the relation between ESOPs and corporate performance runs in the opposite direction: while firms with higher financial returns are more likely to sponsor an ESOP, the adoption of an ESOP does not lead to better performance for such firms. This reverse causality points out potential endogeneity in these studies. By reviewing the literature of ESOPs, Blasi et al. (2003) show considerable diversity among outcomes about the performance-ESOP relation.

With our unique sample of Chinese ESOPs, we are able to conduct a more direct investigation into this relation by highlighting the role of employee motivation. China's economic reform has generated decades of economic growth at high levels. The factors behind the sustained growth appear to be complex and remain unresolved. It has been one of the major objectives of the Chinese government to motivate the employees of its SOEs and, as part of the economic reform agenda, the government introduced the ESOP purely as an incentive scheme. Despite the long debate among researchers and government officials on the use of ESOPs, the role of ESOPs in employee motivation appears to be well accepted. In particular, in the absence of well-designed incentive schemes in China, ESOPs can play a more important role in providing employee incentives than those in a developed corporate governance system. Our sample has another distinct advantage: because a Chinese ESOP does not provide a tax benefit, and employee shares in China play no role in corporate restructuring decisions, our results are not complicated by any tax saving or corporate control effects.

Our sample consists of all 750 firms listed on the Shanghai Stock Exchange (SHSE) and Shenzhen Stock Exchange (SZSE) during the period 1996-2000 among which 251 adopted an ESOP. We compare performance between ESOP and non-ESOP firms by controlling for firm and industry characteristics. We examine several performance measures that include ROA, ROE, 
Tobin's q, and productivity. Our comprehensive examination of performance measures results in a consistent finding: ESOP firms do not perform differently from their non-ESOP counterparts. We obtain this finding from each of the performance measures and it holds in various robustness checks. This finding does not support the proposition that ESOPs improve corporate performance. On the other hand, the finding is consistent with the view that due to the free-rider problem, highly diffused equity ownership among employees under an ESOP does not meaningfully affect employee incentives and thus corporate performance.

Our study provides the first evidence on Chinese ESOPs. The unique regulatory background and experimental nature of the ESOP in China distinguish our study from previous ones in two notable aspects. First, because the short-lived policy on the ESOPs provides a setting close to a natural experiment, our results are unlikely to suffer from endogeneity. Second, the Chinese ESOP was introduced solely as an employee incentive scheme, which is different from those in the U.S. and other countries that serve as alternative pension plans and involve complex governance issues. We also note that, in China, important incentive schemes that are common in a developed market, such as high-powered bonus plans and stock options, are either negligible or simply do not exist. Therefore, without the interaction with alternative incentive or governance mechanisms, the Chinese ESOP allows us to document clean evidence on the role of ESOPs in employee motivation, uncontaminated by the potential effects of tax-saving benefits, corporate control, and incentive contracting.

This paper is organized as follows. Section 2 presents two testable hypotheses that we derive from economic theory for the effects of ESOP adoption on corporate performance. Section 3 describes the institutional and policy background of the Chinese ESOP. Section 4 discusses the method and data that we use in our examination. Section 5 presents our main empirical results. 
Section 6 concludes.

\section{Two competing hypotheses}

ESOPs can affect corporate performance in different ways that may or may not involve employee motivation. Factors other than employee motivation include tax benefits and corporate control motives that are shown to have immediate or short term effects on the firm's post-ESOP adoption performance (see, e.g., Scholes and Wolfson, 1990; Beatty, 1995). Economists are particularly concerned with the role of ESOPs in enhancing employee incentives because work incentives influence the firm's sustainable performance in the longer run. Since Chinese ESOPs involve neither tax-saving benefits nor corporate-control motives, our sample presents a desirable setting that allows us to examine the performance-ESOP relation for the effect of employee motivation.

Agency cost occurs in the modern corporation due to the separation of ownership and control (Jensen and Meckling, 1976). A reasonable approach to mitigating this problem is to make the workers, including the manager, the owner of the firm. Therefore, from agency theory, we expect to find a direct effect of ESOPs on employee motivation that works to improve the firm's performance. This increased motivation directly derives from employees' greater benefit in the firm's improved performance. In addition, it is argued that ESOPs help develop a more productive corporate culture that, by encouraging employee participation and promoting group cooperation, further strengthens the positive effect of ESOPs on corporate performance

(Weitzman and Kruse, 1990; Craig, 1993; Kim and Ouimet, 2009). For such mechanisms we pose the following testable hypothesis:

Hypothesis 1. By enhancing employee motivation, ESOPs improve corporate performance. 
Therefore, there is a positive association between corporate performance and the adoption of ESOPS.

Although this effect is theoretically appealing, its economic significance is debatable. The effectiveness of employee-incentive benefits depends on the strength of the underlying payperformance link. When equity shares in an ESOP are allocated to a large number of employees, it is inevitable that the resulting ownership is highly diffused; and hence, due to the well known free-rider problem, might not meaningfully increase employee motivation. This problem is aggravated by low-level employees whose individual efforts exert little influence on the firm's aggregate performance and who essentially see no link between their individual effort and a perceivable personal benefit.

To show this problem, Table 1 summarizes representative studies of ESOPs regarding the implied incentive strength of employee ownership. In a standard approach (see Jensen and Murphy, 1990), we measure the incentive strength by the sensitivity of the value of an individual employee's ownership to the firm's total shareholder value. In the last column, the sensitivities show that for every $\$ 1,000$ increase in shareholder value, the benefit to an average employee is $4.8 \notin$ with the Chinese plan, $1.5 \notin$ with the U.S. plan, $1.4 \varnothing$ with the Korean plan, and merely $0.9 \phi$ with the Japanese plan. These numbers indicate that typically the incentive strength of ESOPs is weak. Some studies note this potential problem (e.g., Blasi et al. 1996; Ding and Sun, 2001) that is highlighted by the summarized findings in Table 1. Intuitively, for an ordinary employee whose effort exerts little influence on the firm, a reward of just a few cents for every $\$ 1,000$ contribution would logically mean little motivation. Because incentive strength does not add up across employees, the law of free-riding is expected to dictate near-zero incentives for individual employees when the firm's sizeable equity shares are allocated to thousands of employees. In the scenario of serious free riding, we have the following competing hypothesis: 
Hypothesis 2. With highly diffused employee ownership, ESOPs do not effectively enhance employee motivation. Therefore, there is no association between corporate performance and the adoption of ESOPs.

\section{Employee stock ownership plans in China}

The Chinese ESOP has two distinct features: It is a direct product of China's economic reform that started in the late 1970s, and was introduced purely as an employee incentive scheme. The main objective of the reform was to introduce market-economy mechanisms into the old system of central planning to improve resource-allocation efficiency and increase productivity. Ever since the beginning of the reform, the Chinese government's continuing objective has been to enhance employee work incentives for its state-owned enterprises, which are legally owned by the state and administered by central, provincial, or local governments. Early reform measures included increasing managerial decision autonomy and implementing incentive-based corporate tax schemes. Although such measures seemed useful in improving the productivity of SOEs in the 1980s (Groves et al., 1994; Jefferson et al., 1996; Li, 1997), their roles were constrained by complex institutional and market conditions and thus did not generate sustained performance. In the early 1990s, the government introduced more drastic reform measures that were intended to change the ownership structure of SOEs. The implementation of what was called the "shareownership scheme" started the corporatization process under which the Chinese government allowed SOEs to be privatized. ${ }^{1}$ Small firms could be privatized through restructuring, and middle- and large-sized firms could be partially privatized through "share-issue privatization," by

\footnotetext{
${ }^{1}$ Jiang et al. (2009) show that the privatization of Chinese SOEs has become more effective in enhancing firm profitability after the capital market has become more developed.
} 
listing on the two national stock exchanges, SHSE and SZSE.

The ESOP was introduced as a by-product of the corporatization process. Employee stock ownership did not exist in China until May 1992, when China's Economic System Reform Commission (CESRC) announced trial policies for corporatization. ${ }^{2}$ Under such policies, a stateowned enterprise could be restructured and transferred into a limited liability company held by multiple shareholders. ${ }^{3}$ At the time of being incorporated, the company was allowed to issue a portion of equity shares to its employees. Incorporated companies can apply for public listing subject to approval by China Securities Regulatory Commission (CSRC).

This wave of corporatization substantially changed the ownership structure of Chinese firms. After ownership restructuring and depending on its owners' background, a previously stateowned firm would typically have five types of shares: state shares, legal-person shares, employee shares, domestic-individual shares, and foreign shares. State shares are held by central, provincial, or local governments; or by solely government-owned enterprises. Legal-person shares are those held by domestic institutions, including insurance companies, mutual funds, and other enterprises, of which many are partially owned by governments at different levels.

In the early stage, applications for an ESOP were handled by local government authorities; and, due to a lack of effective monitoring, irregularities were common. For instance, it was required that a firm's employee ownership should not exceed $20 \%$ of the firm's total equity shares. Not all firms followed this requirement and some issued more shares to their employees.

\footnotetext{
${ }^{2}$ Chen et al. (1997) compile, in great detail, laws and regulatory rules enacted until the mid 1990s regarding incorporation and securities in China.

${ }^{3}$ An incorporated company must have at least three start-up shareholders. Usually, state agents and local institutions that have financial or business links with the company act as the start-up shareholders.
} 
Initially, employee shares were allowed to trade immediately after the stock was listed and the market treated such shares the same as publicly held stocks. Because the shares under an ESOP were issued at the stock's par value, there was typically a large discount and employees immediately benefited upon the listing of the stock. Thus, the ESOP was quickly recognized as a way to transfer the wealth of state-owned companies to employees and managers. This potential benefit stimulated all eligible firms to apply for an ESOP or plan to apply.

In response to early irregularities, the state regulatory authority issued more stringent rules on the issuing and trading of employee shares. In April 1993, the CESRC released urgent regulatory measures for tightening up on the issuance of employee stock shares. The measures became effective immediately, substantially slowing down the pace of ESOP approval. The measures also stipulated that employee shares could not be transferred in any way to non-employees and, when the stock was listed, employee shares could not trade until three years later. This stipulation affected all firms with an approved ESOP, of which many eventually went public. The latter companies present the majority of the ESOP firms included in our sample.

In July 1993, the CESRC announced more comprehensive rules on issuing employee shares. Although the CESRC stuck to the existing restrictions on the transaction and transfer of employee ownership, the new rules made a significant change by lowering the maximum level of employee shares from the previous $20 \%$ to a mere $2.5 \%$.

The year-old practice of ESOPs did not seem to generate any quick positive effects on company performance. Instead, it created unexpected problems and irregularities (Chen et al., 1997; Chen, 2006), which urged the regulatory authority to reassess the experiment. A few months later, the CESRC moved to completely suspend all ESOP applications. A regulatory notice was released in June 1994 that officially ended the process of adopting ESOPs. While no 
more applications have been approved since then, all previously approved ESOPs are still subject to the rules enacted in April and July of 1993.

Even though the process of adopting ESOPs ended in 1994, there has been a continuing debate among researchers and the public on the roles of ESOPs. This debate was renewed by the wave of public listings of China's major banks in 2006. As a consequence of China's entry into the World Trade Organization, there were increasing pressures on the Chinese government to speed up the reform of its predominantly state-owned banks. Consequently, top four banks have gone public since 2005 and more are expected to follow. Along with this significant financialsector reform, major banks have suggested that the government renew the policy on ESOPs and allow banks to allocate equity shares to their employees. As a response, the Governor of China's Central Bank, Dr. Xiaochuan Zhou, commented publicly on the policy (Chen, 2006). Although he cautioned about the use of ESOPs and called for attention to the chaotic situation during the earlier experiment, his comments hinted at the possibility that China may again allow firms to adopt ESOPs.

The policy experiment with ESOPs in China presents a unique experiment in which the factors in the firm's adoption of the ESOP are largely exogenous. These factors reflected China's economic reform policies and complex political constrains, but were irrelevant to incentive contracting at the individual firm level. Indeed, when the two national stock exchanges were established in 1990, the general public in China had little knowledge about securities markets, and, even years after that, there were serious doubts about the function of stock markets. This is the background when China's economic reform authority proposed ESOPs. Managers of stateowned companies in the early 1990s were totally unfamiliar with the concept of ownership incentives. However, they had no problem in realizing ESOPs' potential benefit to employees. 
On the other hand, whether and when a firm's application for adopting an ESOP could be approved depended on the official approving process, which was handled by varying local governments. This process was usually slow, unpredictable, and irregular. When the June 1994 announcement was released to terminate the experimental policy, many firms missed the opportunity to adopt an ESOP simply because they had either applied late or their applications had been delayed by the inefficient bureaucracy.

The lack of alternative incentive schemes in China further highlights the natural-experiment feature of Chinese ESOPs. In the 1990s, important incentive mechanisms that are common in a developed market, such as high-powered bonus plans, restricted stock awards, and stock options, were either negligible or simply did not exist in China. Therefore, potential employee incentives from ESOPs could not interact with alternative incentive mechanisms.

\section{Method and data}

\subsection{Empirical model}

Chinese firms adopt ESOPs before going public; so there is no information publicly available on performance surrounding the adoption and we cannot examine the change in performance from the pre-adoption period to the post-adoption period. In this study, we focus on crosssectional comparisons of performance over a post-adoption period between ESOP and nonESOP firms. Specifically, we investigate the first few years after the firm goes public during which employee shares are subject to stringent regulatory restrictions on transfer and transaction. We examine several performance measures that include ROA, ROE, Tobin's q, and productivity. Tobin's q is calculated as the ratio of the market value of equity plus the book value of long-term debt over the book value of total assets. Following previous studies of Chinese firms (e.g., Sun 
and Tong, 2003; Chen et al., 2009), we also examine the return on sales (ROS), which is the ratio of net income to sales. Furthermore, we examine IPO pricing to see whether the market values ESOP and non-ESOP firms are different at that time.

Many firm variables can affect these performance measures. Firm size and industry, in particular, are two important factors that affect both corporate performance and incentive contracts. We control for these two factors by constructing matching firms with which we match ESOP with non-ESOP firms. Ownership structure presents another important factor affecting the performance of Chinese firms. Qi et al. (2000), Sun and Tong (2003), and Wei et al. (2005) find company performance has an association with state and legal-person shares. Financial leverage is also relevant and, as shown in Qi et al. (2000), Sun and Tong (2003), Yuan et al. (2008), and Margaritisa and Psillaki (2010), its effect can be complex. Bai and Wang (1998) argue that financial leverage in China's state-owned enterprises reflects Kornai’s (1980) soft budget constraint that adversely affects firm performance. Wang (2011) suggests that the interaction of financial leverage with managerial entrenchment affects the firm's payout policy and shareholder value. In addition, the timing of a firm's incorporation might also have a link to its performance, because it might reflect the firm's stage of development and hence can be associated with certain levels or patterns of production.

Our baseline empirical model has the following specification:

$$
Y_{i t}=\beta E S O P_{i}+\sum_{n} \gamma_{n} C V_{n t}+\alpha_{k}+\tau_{t}+\varepsilon_{i t}
$$

where $Y_{i t}$ represents firm $i$ 's performance (ROA, ROE, ROS, or Tobin's q) in year $t$. ESOP $P_{i}$ is a dummy variable that takes a value of one if the firm adopts an ESOP, and zero otherwise. The 
second term, $\sum_{n} \gamma_{n} \times C V_{n t}$, represents a set of control variables that capture firm characteristics. These variables are the logarithm of total assets, debt-to-equity ratio, state shares and legalperson shares as a percentage of the firm's total shares, and firm age. Firm age is calculated as the number of years from a firm's incorporation to its listing. $\alpha_{k}$ represents industry effects, which captures time-invariant industry heterogeneity. We note that the manufacturing sector represents $60 \%$ of our sample firms and the CSRC industry classification further divides the manufacturing sector into ten subsectors. Therefore, we use 22 dummy variables to differentiate between the industry sectors (12 broad industry sectors and ten manufacturing subsectors). $\tau_{t}$ represents year effects, which captures technological change and macroeconomic or market factors that are common to all firms. $\varepsilon_{i t}$ is the error term that follows a normal distribution.

Our main focus is on the coefficient of the ESOP dummy, $\beta$. When ESOPs are effective in enhancing employee motivation, we expect $\beta$ to be significantly positive (Hypothesis 1 ). On the other hand, in the presence of a serious free-rider problem, we expect $\beta$ to be statistically nonsignificant from zero (Hypothesis 2).

\subsection{Data}

Our sample consists of all firms listed on China's two stock exchanges, SHSE and SZSE, from January 1996 to December 2000. We exclude firms listed before 1996 because some of the firms listed in the early years did not follow the regulatory requirement for holding employee shares from trading for three years after its public listing. With this exclusion, we also mitigate potential problems associated with market irregularities and policy changes in the early 1990s when China's stock markets were in the early stages of development. In addition, the number of 
ESOP firms that went public after 2000 becomes very small, so we also exclude firms listed after 2000 .

We obtain our data from two widely used databases of Chinese firms. We use the financial information database, GTIOne, distributed by Genius Information Technology Co. GTIOne provides corporate financial data and information on ownership structure and the date of the IPO. Our other source is the Chinese Stock Market \& Accounting Research Database distributed by Guo Tai, An Information Technology Co., from which we obtain information on stock-price performance.

In Table 2, Panel A summarizes the firm listings on the two stock exchanges during the years 1996-2000. In this period, total 750 firms were listed of which 251 had an ESOP. The first row shows a clear pattern of diminishing listings for ESOP firms, which is consistent with the fact that no ESOPs were approved after June 1994. On the other hand, the listing of non-ESOP firms is relatively stable during this period. We confine our examination to the first six years after the firm's listing, including the IPO year. Because employee shares become publicly tradable three years after listing, the six-year examination window covers the three years under regulatory constraints on employee shares transactions and the three years without such constraints. ${ }^{4}$

Panel B shows the industry composition of the sample firms. Following the industryclassification guideline announced by CSRC, Chinese firms are classified into 13 broad industries. ${ }^{5}$ More than half of the firms, either with or without an ESOP, fall into the manufacturing sector. Except for the conglomerate sector, the industry distribution does not

\footnotetext{
${ }^{4}$ Because our sample covers the 1996-2003 data period, companies listed in 1999 and 2000 have observations of less than six years.

${ }^{5}$ The industry classification guideline is available at CSRC's official website (www.csrc.gov.cn).
} 
show clear differences between ESOP and non-ESOP firms.

Table 3 shows the distribution of employee ownership as a percentage of the firm's total shares in the IPO year. The second column presents the percentage based on the firm's total tradable and non-tradable shares. State shares and legal-person shares are both non-tradable shares. ${ }^{6}$ The average aggregate employee ownership under the ESOP is $12 \%$, which is close to the employee ownership level under U.S. ESOPs (e.g., Conte et al., 1996) but substantially higher than that under Japanese plans (Jones and Kato, 1995) and Korean plans (Cin and Smith, 2002). The distribution shows a large cross-firm variation in employee ownership. Among the 251 firms with an ESOP, 35 have employee ownership higher than 20\%. Apparently, most of these firms adopted their ESOP before 1994 and did not meet the regulatory requirement for the employee-ownership ceiling of $20 \%$. The forth column presents the distribution of employee shares as the percentage of total tradable shares only. The percentages are substantially higher, of which 16 even exceed the firm's total tradable shares.

To deal with potential data error and outliers, we winsorize the performance data by removing the top and bottom $1 \%$ of the observations for each of the performance measures. We then construct the matching sample. For each ESOP firm, we identify a matching firm from the non-ESOP group. The choice of the matching firm satisfies the following conditions: it must be listed in the same year as the ESOP firm, it must be in the same industry (based on the CSRC industry classification of 13 broad industry sectors) in that year, and have a size similar as the

\footnotetext{
${ }^{6}$ There has been an increasing concern of both regulators and investors that the dismal performance of Chinese stocks in the past few years might partly be due to the existence of massive illiquid nontradable shares. A regulatory change took place in 2006 that allows firms to gradually convert nontradable shares to tradable shares.
} 
ESOP firm. We measure firm size by sales and require the matching firm's sales be between 70 and $130 \%$ of the ESOP counterpart. This matching process results in 189 pairs of ESOP and nonESOP firms that are matched by size, industry, and listing year.

As a robustness check, we also examined other size variables, such as the firm's total assets and market capitalization. With such alternative size variables, we find no meaningful differences to our main results. Therefore, we only report and discuss the results obtained using sales as the size measure.

Table 4 presents summary statistics of selected firm variables. Panel A shows the statistics for the total sample and Panel B for the matched sample, separating ESOP firms from non-ESOP firms. For the total sample, although the statistics do not seem to differ much between ESOP and non-ESOP firms, there are some notable differences. First, on average, ESOP firms are smaller than non-ESOP firms. This size difference might reflect the difference in industry composition between the two groups. As shown in Table 2, while more non-ESOP firms are in the mining and manufacturing sectors, which are typically large companies, relatively more ESOP firms are in the sectors of wholesale and retail trade, real estate, and conglomerate. Second, firm age is two to three years older for ESOP firms than for non-ESOP firms. This difference is related to the fact that all ESOP firms were incorporated before June 1994 when the trial policy on ESOPs was officially ended. Third, ESOP firms have an average state ownership of about $25 \%$, while the average ownership is as high as $33 \%$ for non-ESOP firms. This observation squares with the fact that ESOP firms allocated an average of $12 \%$ of their total equity shares to their employees.

Panel B shows the statistics for the matched sample. After differences in industry composition and size distribution between the two groups are removed, the matched sample indicates similar firm characteristics between ESOP and non-ESOP firms. The controlled 
homogeneity in size is of particular importance, because firm size is associated with both firm performance measures and incentive intensity measures and the associations are nonlinear and difficult to control ideally. For comparison purposes, in our discussions we will report empirical results for both the total sample and the matched sample.

Table 5 compares the long-term changes of tradable shares between ESOP and non-ESOP firms. The numbers indicate a sharp difference in the over-time changes between the two groups. All firms' tradable shares increase consistently after the IPO. For non-ESOP firms, the increase is relatively stable, mostly at a rate of 15 to $20 \%$ per year. However, for ESOP firms, the increase is markedly elevated in the third and fourth years, reaching an average rate of as high as $70 \%$. The difference between the two groups in these two years is large and statistically significant. This difference directly results from the ESOPs under which employee shares become regular tradable shares after three years and the change is indicated in the firm's annual report for the third or fourth fiscal year.

\section{Empirical results}

\subsection{Base regressions}

Table 6 presents the total-sample regressions of the four performance measures, ROA, ROE, ROS, and Tobin's q, on the adoption of the ESOP. The regressions control for firm characteristics and include industry and year fixed effects, and the results are qualitatively similar between the total-sample and the matched-sample regressions. The key parameter estimate is the coefficient on the ESOP dummy, which has mixed signs and is statistically nonsignificant from zero in all of the regressions (except one that is marginally significant with

the total sample). The consistently small magnitude and low significance level of this coefficient 
reject Hypothesis 1 that predicts better performance for ESOP firms. On the other hand, this observation supports Hypothesis 2, which shows a statistically insignificant difference in the performance between ESOP and non-ESOP firms.

The coefficients for the control variables are mostly consistent with previous studies, giving us four observations. First, there is a significant size effect on the performance measures. The coefficient on the logarithm of total assets is significantly positive in the regressions on the three return performance measures and significantly negative in the regression on Tobin's q. Because Tobin's q is also a proxy for growth potential and declines as firms grow, the difference between it and the returns is expected.

Second, the debt-to-equity ratio has a significantly negative effect on firm performance. This result is inconsistent with standard capital structure theory that predicts higher default risk and thus higher returns for firms with higher financial leverage. On the other hand, a negative effect for debt is in line with the soft-budget constraint theory (Kornai, 1980). Since our firms are mostly owned or controlled by the state and are more likely to have a soft-budget constraint problem, it is not unexpected that firms with more debt perform poorly compared with those with less debt.

Third, the coefficients on state shares and legal-person shares suggest a complex link between company performance and ownership structure, and this link differs between the performance measures. Previous studies (e.g., Qi et al., 2000) do not give conclusive results on this link. Indeed, there is a debate on the roles of legal-person shares and state shares in China regarding corporate governance. Since legal persons are mostly state-owned or controlled companies or institutions and any shares held by legal persons are essentially indirect state shares, the monitoring role of legal-person shares is unlikely to be fundamentally different from that of 
state shares. ${ }^{7}$ Chen et al. (2009) argue that different types of owners have different objectives and motivations, and show that private ownership of listed firms in China is not necessarily superior to certain types of state ownership. $\mathrm{Ng}$. et al. (2009) argue that the relation between state shares and performance is convex.

Further, firm age has a negative association with the performance measures. One possible explanation for this result is that firms time their decision to become incorporated. When firms can choose a favorable time for incorporation, their post-incorporation performance should decline in a way similar to IPO long-run performance (Ritter, 1991). In China, a firm needs at least three start-up shareholders to sponsor its application for incorporation. Hence, the firm might have a strong incentive to time the decision so as to attract important institutional investors and "window-dress" its performance. And the effect of such firm behaviors should be more evident with the accounting performance measures such as ROA and ROE.

These total-sample regressions do not allow the ESOP effect to change with years, so it is possible that this effect does not show up in the total sample because it is time variant. Jones and Kato (1995) show that in their Japanese sample, the ESOP effect is negative in the first year after a firm adopts the ESOP and the effect turns positive in the third year. For this reason, we also run the by-year regressions for each of the six firm-data years.

Table 7 summarizes the coefficient on the ESOP dummy for the by-year regressions of all four performance measures. Since the coefficients on the control variables give few additional insights, we do not report them in this table. Out of a total of 48 parameter estimates for the

\footnotetext{
${ }^{7}$ Hence, legal persons in China are quite different from institutional shareholders in the U.S., who, as Hartzell and Starks (2003) argue, "serve an important monitoring role in mitigating the agency problem between shareholders and managers."
} 
effect of ESOPs, only one is statistically significant and three marginally significant, with inconsistent signs. The $t$-ratios are mostly small and the signs are mixed. Reinforcing our observation from Table 6, these by-year regressions show no meaningful differences in performance between ESOP and non-ESOP firms.

Jones and Kato (1995) suggest that the ESOP effect is likely to show up in the third year after adopting an ESOP. Since the majority of the ESOP firms in our sample went public a few years after they adopted the plan, if there is a positive effect, this effect should be evident for at least a few years after listing. Our results apparently do not support this empirical regularity.

To further confirm our findings, we also examine alternative model specifications. To capture the ownership effect, we use employee ownership as a percentage of total shares, instead of using a dummy variable for the ESOP group, in the regressions. To allow a nonlinear effect, we use quadratic forms for employee ownership and for the control variables. We also estimate the models by removing industry dummies in order to avoid potential problems arising from time-invariant effects of ESOPs. In all alternative regressions, our results remain qualitatively the same as those reported in Tables 6 and 7. We conclude that the evidence from the regressions of the three accounting return performance measures and Tobin's q indicates no difference in performance between firms with an ESOP and those without.

\subsection{Productivity}

To identify the effect of ESOPs, many previous studies also examine the firm's productivity (e.g., Jones and Kato, 1995; Cin and Smith, 2002; Hu and Zhou, 2008). Following this literature, we further compare productivity between ESOP and non-ESOP firms, using two models for the production function. The first model is a standard Cobb-Douglas specification: 


$$
\ln Q_{i t}=\varphi_{K} \ln K_{i t}+\varphi_{L} \ln L_{i t}+\beta E S O P_{i}+\sum_{n} \gamma_{n} C V_{n t}+\alpha_{k}+\tau_{t}+\varepsilon_{i t}
$$

where $Q_{i t}$ is firm $i$ 's total output in year $t$, which we calculate as total sales minus direct operating costs as an approximation to value added; $K_{i t}$ represents total capital; and $L_{i t}$ represents total employees. The control variables in (2), including industry and year effects, are similarly defined as in model (1). The second model we estimate uses a Translog production function:

$$
\begin{aligned}
\ln Q_{i t} & =\varphi_{K} \ln K_{i t}+\varphi_{L} \ln L_{i t}+\varphi_{K K}\left(\ln K_{i t}\right)^{2}+\varphi_{L L}\left(\ln L_{i t}\right)^{2}+\varphi_{K L}\left(\ln K_{i t} \times \ln L_{i t}\right) \\
& +\beta E S O P_{i}+\sum_{n} \gamma_{n} C V_{n t}+\alpha_{k}+\tau_{t}+\varepsilon_{i t} .
\end{aligned}
$$

Table 8 presents the regressions for the two production functions. Because the data on labor are only available beginning in 1999, the regressions in this table are run for the period of 1999-2003. In all four regressions, the coefficient on the ESOP dummy is very small and statistically nonsignificant from zero. Consistent with our examination of the accounting returns and Tobin's q, the productivity models show little difference between the two groups, strengthening the notion that ESOPs do not impact company performance. While it again rejects Hypothesis 1, this result lends further support to Hypothesis 2.

Two additional observations are worth noting on the coefficients on capital and labor in the Cobb-Douglas production regressions (the first and third columns). First, the sum of the two coefficients is close to 1.1 , indicating increasing returns to scale. Second, the coefficient on capital is close to one, while that on labor is only $10 \%$. The substantially low marginal product of labor is in stark contrast to the usual case with developed economies. Together with the statistics shown in Table 4, this second observation indicates that the production of Chinese firms in the 1990s was labor intensive and characterized by low levels of labor productivity.

\subsection{Robustness}


Table 3 shows that 35 firms with an ESOP have employee ownership higher than the regulatory upper limit of $20 \%$ of total equity shares. Although such firms only represent a small minority (less than $14 \%$ of the ESOP sample), they can potentially affect our test if they are inherently different from other firms and have a different motivation for adopting the ESOP. To clarify, we first compare summary statistics between these 35 firms and other ESOP firms, and then run the regressions in Tables $6-8$ specifically for them. The summary statistics do not show any notable difference between these firms and other ESOP firms. In particular, with the various performance measures, we find no meaningful difference in performance between these firms and non-ESOPs.

We have so far ignored potential effects of corporate events such as mergers and acquisitions (M\&A), seasoned equity offerings (SEO), share repurchases, and debt issuances. To conduct robustness checks in this regard, we identify corporate events from Wind Financial Database distributed by Wind Info, a leading financial data and software provider in China. During the period of 1996-2003, which our performance data cover, M\&As with Chinese firms were quite frequent; each year, about $30 \%$ of all firms experience a M\&A event. The frequency of the events shows little difference between ESOPs and non-ESOPs, while it increases slowly over time in the six years after the firm is listed. On the other hand, other corporate events were scarce during the sample period; each year, about $1 \%$ or less of firms experience a corporate event other than a M\&A. With our sample, there are a total of 47 SEOs, 2 repurchases, 27 debt issues, and no debt retirement, of which the distributions do not show a clear difference between ESOPs and nonESOPs. We use dummy variables for the corporate events and add them, in various manners, to the regression models in Tables 6-8: using the M\&A dummy, SEO dummy, other corporate events dummy (all events except M\&A) separately, and using all event dummy variables together. Our 
regression results with the event dummy variables change little from those we discuss above, again showing no meaningful difference in performance between ESOPs and non-ESOPs.

\subsection{Stock valuation}

In an efficient market, the price of the firm's stock follows its fundamental value. If ESOPs play a significant role in enhancing employee incentives, this role should be translated into improved fundamentals and thus higher market value. Therefore, if an ESOP firm is superior to an otherwise equivalent non-ESOP firm, then at the time when they are listed, the market should price the stock with an ESOP higher than that without it. Based on this prediction, we compare stock valuation between the ESOP group and the non-ESOP group by focusing on the pricing of their IPOs.

Table 9 presents the result for this comparison, and from which we obtain two interesting observations. First, the first-day closing price (the first row on Panels A and B) shows that the market is indifferent to valuing the new stock between ESOP and non-ESOP firms. In support of this finding, the matched sample, which removes size and industry heterogeneity between the two groups, indicates a nonsignificant difference between the two groups in the market capitalization of total tradable shares at the first-day closing price. This observation is in line with our findings from other performance measures, including Tobin's q in particular, and casts further doubt on the proposition that ESOPs improve corporate performance.

In case non-tradable shares make a difference, we also compare the market value of nontradable shares at the first-day closing price between the two groups. Just as with tradable shares, we find no meaningful difference in the value of non-tradable shares between ESOP and nonESOP stocks. 
We note that the potential market imperfections of the Chinese equity market might cause inefficient market behaviors, so it is possible that the pricing information in the immediate aftermarket does not reflect the effect of ESOPs. ${ }^{8}$ However, although market inefficiency can contribute to our observation, we suspect that the role of this potential factor is very limited. The accounting return performance measures we examine earlier are more indicative of the firm's fundamentals, which are not likely to be affected by market inefficiency. Moreover, the q measure, which directly depends on equity market valuation, does not show any meaningful effect from ESOPs even several years after the stock is listed.

Our second observation is that ESOP stocks are offered at higher prices than are non-ESOP stocks. This finding is particularly strong with the matched sample, where the average offer price of ESOP stocks is $17.4 \%$ higher than that of non-ESOP stocks. Given our first observation that the firm's fundamental value is unaffected by the ESOP, the implication of higher offer prices for ESOP stocks seems apparent. When the manager and employees of the issuing firm with an ESOP see a direct link between the new issue price and their personal wealth in employee shares, the firm should have a stronger incentive to negotiate for a higher offer price. The rationale here is that to raise the same amount of equity capital, a higher offer price causes less dilution to existing equity, including employee shares.

As a result of the same fundamental values but different offer prices, the initial return is different between ESOP and non-ESOP stocks. The initial return, calculated as the first-day closing price minus the offer price divided by the offer price, is significantly lower for ESOP firms than for non-ESOP firms. The difference is highly significant statistically and economically; with the matched sample, for instance, the average initial return for ESOP firms is

\footnotetext{
${ }^{8}$ Eun and Huang (2007) examine market imperfections of the Chinese equity market.
} 
only $50 \%$ of that for non-ESOP firms. This finding appears to suggest different negotiation mechanisms between the two groups of issuers in setting the offer price. Further research is needed before one can draw a conclusion on this interesting issue.

\section{Conclusion}

In this study, we examine the effect of ESOPs on corporate performance by using a sample of Chinese ESOPs that results from a unique policy experiment. After examining a variety of performance measures, including ROA, ROE, Tobin's q, and productivity, we find no meaningful difference in performance between ESOP and non-ESOP firms. This finding is obtained with each of the performance measures and holds in various robustness checks. Consistent with this observation, the equity market values ESOP and non-ESOP stocks indifferently. Reinforcing the findings of some previous studies such as Conte et al. (1996), our test casts further doubts on the presumed role of ESOPs in providing useful employee incentives. On the other hand, our finding supports the prediction of contract theory that highly diffused ownership does not induce meaningful work incentives. Because equity shares under an ESOP are typically allocated to a large number of employees, such plans are likely to incur a serious free-rider problem and hence are ineffective in motivating employees.

Our finding has a direct implication for employee stock option plans, which, by allowing diffused stock option holdings by employees, are also likely to suffer from a free-rider problem. Since the 1990s, stock options have become a popular form of compensation to ordinary employees as well as to managers (Hall and Murphy, 2003). Proponents of this compensation practice applaud the stock-option role in tying the long-term interests of employees and the firm. But the evidence to date for the performance effect of employee stock options is scarce. 
However, this is not totally unexpected because an employee stock option plan usually allocates less than $10 \%$ of the firm's shares in options to its employees. By calibrating U.S. data, Oyer and Schaefer (2005) reach a similar conclusion. Hall and Murphy even consider this problem a troubling factor for employee stock options.

\section{References}

Bai, C., Wang Y., 1998. Bureaucratic control and the soft budget constraint. Journal of Comparative Economics 26, 41-61.

Blasi, J., Kruse, D., Bernstein, A., 2003. In the Company of Owners. Basic Books: New York.

Blasi, J., Conte, M., Kruse, D., 1996. Employee stock ownership and corporate performance among public companies. Industrial and Labor Relations Review 50, 60-79.

Beatty, A., 1995. The cash flow and informational effects of employee stock ownership plans. Journal of Financial Economics 38, 211-240.

Chang, S., Mayers, D., 1992. Managerial vote ownership and shareholder wealth: evidence from employee stock ownership plans. Journal of Financial Economics 32, 103-131.

Chen, D., 2006. A warning from the governor of the central bank: Lessons from the ESOP experiment in the early 1990s. China Business News (May 24).

Chen, G., Zhou, S., and Wu, S., 1997. Regulation and Rules Regarding Securities in China. $2^{\text {nd }}$ edition, Remin University Press: Beijing.

Chen, G., Firth, M., Xu, L., 2009. Does the type of ownership control matter? Evidence from China's listed companies. Journal of Banking and Finance 33, 171-181.

Cin, B., Smith, S., 2002. Employee stock ownership and participation in South Korea: Incidence, productivity effects, and prospects. Review of Development Economics 6, 263-283. 
Conte, M. A., Blasi, J., Kruse, D., Jampani, R., 1996. Financial returns of public ESOP companies: Investor effects vs. manager effects. Financial Analysts Journal 52, 51-61.

Craig, B., 1993. The objectives of worker cooperatives. Journal of Comparative Economics 17 , $288-308$.

Ding, D., Sun, Q., 2001. Causes and effects of employee stock option plans: Evidence from Singapore. Pacific-Basin Finance Journal 9, 563-599.

Eun, C., S., Huang, W., 2007. Asset pricing in China's domestic stock markets: Is there a logic? Pacific-Basin Finance Journal 15, 452-480.

Gordon, L.A., Pound, J., 1990. ESOPs and corporate control. Journal of Financial Economics 27, $525-555$.

Groves, T., Hond, Y., McMillan, J., Naughton, B., 1994. Autonomy and incentives in Chinese state enterprises. Quarterly Journal of Economics 109, 183-209.

Hall, B. J., Murphy, K. J., 2003. The trouble with stock options. Journal of Economic Perspectives 17, 49-70.

Hartzell, J., Starks, L., 2003. Institutional investors and executive compensation. Journal of Finance 58, 2351-2374.

Hu, Y., Zhou, X., 2008. The performance effect of managerial ownership: Evidence from China. Journal of Banking and Finance 32, 2099-2110.

Jefferson, G. H., Rawski, T. G., Zheng, Y., 1996. Chinese industrial productivity: Trends, measurement issues, and recent developments. Journal of Comparative Economics 23, $146-180$.

Jensen, M. C., Meckling, W., 1976. Theory of the firm: Managerial behaviour, agency costs and ownership structure. Journal of Financial Economics 3, 305-360. 
Jensen, M. C., Murphy, K. J., 1990. Performance pay and top-management incentives. Journal of Political Economy 98, 225-264.

Jiang, G., Yue, H., Zhao, L., 2009. A re-examination of China's share issue privatization. Journal of Banking and Finance 33, 2322-2332.

Jones, D. C., Kato, T., 1995. The productivity effects of employee stock-ownership plans and bonuses: Evidence from Japanese panel data. The American Economic Review 85, 391414.

Kim, E. H., Ouimet, P., 2009. Employee capitalism or corporate socialism? Broad-based employee stock ownership. Discussion Papers, US Census Bureau Center for Economic Studies.

Kornai, J., 1980. Economics of Shortage. North-Holland: Amsterdam.

Kumbhakar, S. C., Dunbar, A. E., 1993. The elusive ESOP-productivity link: Evidence from US firm-level data. Journal of Public Economics 52, 273-283.

Li, W., 1997. The impact of economic reform on the performance of Chinese state enterprises, 1980-1989. Journal of Political Economy 105, 1080-1106.

Margaritisa, D., Psillaki, M., 2010. Capital structure, equity ownership and firm performance. Journal of Banking and Finance 34, 621-632.

$\mathrm{Ng}$, A., Yuce, A., Chen, E., 2009. Determinants of state equity ownership, and its effect on value/performance: China's privatized firms. Pacific-Basin Finance Journal 17, 413-443.

Oyer, P., Schaefer, S., 2005. Why do some firms give stock options to all employees? An empirical examination of alternative theories. Journal of Financial Economics 76, 99-133. 
Qi, D., Wu, W., Zhang, H., 2000. Shareholding structure and corporate performance of partially privatized firms: Evidence from listed Chinese companies. Pacific-Basin Finance Journal 8, $587-610$.

Ritter, J. R., 1991. The long-run performance of initial public offerings. Journal of Finance 46, 327.

Scholes, M. S., Wolfson, M. A. 1990. Employee ownership plans and corporate restructuring: Myths and realities. Financial Management 19, 12-28.

Sun, Q., Tong, W., 2003. China share issue privatization: The extent of its success. Journal of Financial Economics 70: 183-222.

U.S. GAO, 1987. Employee stock ownership plans: Little evidence of effects on corporate performance, GAO/PEMD-88-1. U.S. General Accounting Office: Washington, D.C., $10-13$.

Wang, H., 2011, Managerial entrenchment, equity payout and capital structure. Journal of Banking and Finance 35, 36-50.

Wei, Z., Feixue, X., Zhang, S., 2005. Ownership structure and firm value in China's privatized firms: 1991-2001. Journal of Financial and Quantitative Analysis 40, 87-108.

Weitzman, M., Kruse, D., 1990. Profit sharing and productivity. In: A. S. Blinder (Ed.), Paying for Productivity: A Look at the Evidence. Brookings Institution: Washington, D.C.

Yuan, R., Zezhong Xiao, J., Zou, H., 2008. Mutual funds' ownership and firm performance: Evidence from China. Journal of Banking and Finance 32, 1552-1565. 


\section{Table 1. Employee Incentive Strength under Representative ESOPs}

This table summarizes the incentive strength of employee stock ownership plans (ESOPs) from some existing studies that use U.S., Japanese, Korean, and Chinese data. Sample size is the number of firms that adopt an ESOP. Average ESO is the aggregate number of employee shares held under the ESOP as a percentage of the firm's total shares. The incentive strength is calculated as the average ESO per employee, which measures the dollar increase in the value of an employee's ownership for every $\$ 1,000$ increase in the firm's shareholder value.

\begin{tabular}{|c|c|c|c|c|c|}
\hline Country & Sample size & Data year & Average ESO & $\begin{array}{c}\text { Employees in } \\
\text { ESOP }\end{array}$ & $\begin{array}{c}\text { Incentive } \\
\text { strength of ESOP }\end{array}$ \\
\hline U.S. (Chang and Mayers, 1992) & 276 & 1976-1989 & $9.2 \%$ & $6,000^{\mathrm{a}}$ & $\$ 0.015$ \\
\hline Japan (Jones and Kato, 1995) & 109 & $1973-1980$ & $0.9 \%$ & $9,772^{b}$ & $\$ 0.009$ \\
\hline Korea (Cin and Smith, 2002) & 336 & 1996-1997 & $2.2 \%$ & 1,623 & $\$ 0.014^{\mathrm{c}}$ \\
\hline China (this study) & 251 & $1996-2000$ & $12.0 \%$ & 2,496 & $\$ 0.048$ \\
\hline
\end{tabular}

a. A conservative estimate from Conte et al. (1996, Table 2).

b. An estimate from Jones and Kato (1995, Table 1).

c. Two year average from Cin and Smith (2002, Tables 6 and 7). 
Table 2. Listing and Industry Composition of Sample Firms

The sample consists of all 750 firms listed on Shanghai and Shenzhen Stock Exchanges from January 1996 to December 2000 among which 251 adopted an ESOP. Panel A shows the yearly distribution of listings and Panel B shows the industry composition of the sample firms. Firms are divided into 13 broad industry sectors following the industry-classification guideline announced by the China Securities Regulatory Commission.

\section{A. Year distribution of listing}

1996

1997

1998

1999

2000
Listing of ESOP firms

93

76

22

28

32
Listing of Non-ESOP firms

110

130

84

70

105

\section{B. Industry composition of sample firms}

\begin{tabular}{lrlrl} 
& \multicolumn{2}{c}{ ESOP firms } & \multicolumn{3}{c}{ Non-ESOP firms } \\
\cline { 2 - 6 } Agriculture, Forestry, Fishing \& Hunting & 6 & $(2.4 \%)$ & 19 & $(3.8 \%)$ \\
Mining & 1 & $(0.4 \%)$ & 11 & $(2.2 \%)$ \\
Manufacturing & 134 & $(53.4 \%)$ & 315 & $(63.1 \%)$ \\
Electricity, Gas, Water Supply & 11 & $(4.4 \%)$ & 18 & $(3.6 \%)$ \\
Construction & 4 & $(1.6 \%)$ & 8 & $(1.6 \%)$ \\
Transport \& Storage & 13 & $(5.2 \%)$ & 21 & $(4.2 \%)$ \\
Information Technology & 14 & $(5.6 \%)$ & 29 & $(5.8 \%)$ \\
Wholesale \& Retail Trade & 24 & $(9.6 \%)$ & 27 & $(5.4 \%)$ \\
Finance \& Insurance & 0 & $(0.0 \%)$ & 2 & $(0.4 \%)$ \\
Real Estate & 9 & $(3.6 \%)$ & 6 & $(1.2 \%)$ \\
Social Services & 9 & $(3.6 \%)$ & 22 & $(4.4 \%)$ \\
Transmission \& Culture & 0 & $(0.0 \%)$ & 4 & $(0.8 \%)$ \\
Conglomerate & 26 & $(10.4 \%)$ & 17 & $(3.4 \%)$ \\
Total & 251 & $(100 \%)$ & 499 & $(100 \%)$
\end{tabular}


Table 3. Distribution of Employee Ownership under ESOPs

This table shows the distribution of employee share ownership under the ESOP in the year when the firm goes public. EO represents employee ownership as a percentage of the firm's total shares.

\begin{tabular}{|c|c|c|c|c|}
\hline \multirow{2}{*}{ EO range (\%) } & \multicolumn{2}{|c|}{$\begin{array}{l}\text { (As the percentage of total tradable } \\
\text { and non-tradable shares) }\end{array}$} & \multicolumn{2}{|c|}{$\begin{array}{l}\text { (As the percentage of total } \\
\text { tradable shares) }\end{array}$} \\
\hline & Mean EO (\%) & Number of firms & Mean EO (\%) & Number of firms \\
\hline $1-5$ & 2.9 & 56 & 4.0 & 5 \\
\hline $5-10$ & 7.7 & 51 & 7.4 & 23 \\
\hline $10-15$ & 12.6 & 88 & 12.7 & 19 \\
\hline $15-20$ & 17.3 & 21 & 17.4 & 14 \\
\hline $20-25$ & 22.4 & 16 & 23.5 & 10 \\
\hline $25-30$ & 27.7 & 9 & 27.5 & 23 \\
\hline $30-35$ & 32.1 & 4 & 33.1 & 17 \\
\hline $35-40$ & 37.6 & 2 & 38.8 & 15 \\
\hline $40-45$ & 41.4 & 2 & 43.1 & 19 \\
\hline $45-50$ & 48.1 & 2 & 47.8 & 19 \\
\hline $50-55$ & & & 52.4 & 21 \\
\hline $55-60$ & & & 58.3 & 12 \\
\hline $60-65$ & & & 62.3 & 7 \\
\hline $65-70$ & & & 67.4 & 3 \\
\hline $70-75$ & & & 73.1 & 5 \\
\hline $75-80$ & & & 77.2 & 6 \\
\hline $80-85$ & & & 82.3 & 5 \\
\hline $85-90$ & & & 89.6 & 3 \\
\hline $90-95$ & & & 92.9 & 5 \\
\hline $95-100$ & & & 97.5 & 4 \\
\hline Above 100 & & & 148.8 & 16 \\
\hline ALL & 12.0 & 251 & 46.2 & 251 \\
\hline
\end{tabular}




\section{Table 4. Summary Statistics}

This table presents summary statistics for selected firm variables for the total sample and the matched sample, separating ESOP from non-ESOP firms. The total sample consists of all 750 firms listed on Shanghai and Shenzhen Stock Exchanges from January 1996 to December 2000 among which 251 adopted an ESOP. The data cover the eight-year period from 1996 to 2003. We obtain the data from two widely used databases of Chinese firms: the Financial Information Database distributed by Genius Information Technology Co. and the Chinese Stock Market \& Accounting Research Database distributed by Guo Tai An Information Technology Co. The matched sample consists of 189 pairs of ESOP and non-ESOP firms that are matched by size, industry, and listing year. Firm age is calculated as the number of years of a firm's incorporation. The data on employees are available only for the years of 1999-2003.

\begin{tabular}{|c|c|c|c|c|}
\hline Variable & Mean & Median & Stand. Dev. & Observation \\
\hline \multicolumn{5}{|c|}{ A: Total sample } \\
\hline \multicolumn{5}{|l|}{ ESOP firms: } \\
\hline Asset (Millions RMB) & $1,381.95$ & $1,013.08$ & $1,529.05$ & 1,413 \\
\hline Sales (Millions RMB) & 684.61 & 406.75 & 901.37 & 1,409 \\
\hline Total employees & $2,495.90$ & $1,657.00$ & $2,976.87$ & 861 \\
\hline State Ownership (\%) & 24.97 & 24.97 & 21.46 & 1,412 \\
\hline Legal Person Ownership (\%) & 30.18 & 27.53 & 21.60 & 1,412 \\
\hline Debt-to-Equity & 0.20 & 0.07 & 0.70 & 1,386 \\
\hline Firm Age at IPO (year) & 4.61 & 4.00 & 2.14 & 251 \\
\hline \multicolumn{5}{|l|}{ Non-ESOP firms: } \\
\hline Asset (Millions RMB) & $2,445.31$ & $1,014.63$ & $13,662.80$ & 2,714 \\
\hline Sales (Millions RMB) & $1,128.11$ & 443.73 & $2,400.00$ & 2,712 \\
\hline Total employees & $2,800.23$ & $1,799.00$ & $3,206.68$ & 1,807 \\
\hline State Ownership (\%) & 32.95 & 36.12 & 30.22 & 2,714 \\
\hline Legal Person Ownership (\%) & 32.34 & 27.36 & 29.77 & 2,714 \\
\hline Debt-to-Equity & 0.15 & 0.05 & 0.50 & 2,676 \\
\hline Firm Age at IPO (year) & 2.16 & 1.00 & 3.71 & 499 \\
\hline \multicolumn{5}{|c|}{ B. Matched sample } \\
\hline \multicolumn{5}{|l|}{ ESOP firms: } \\
\hline Asset (Millions RMB) & $1,397.00$ & 1048.40 & $1,340.48$ & 1,060 \\
\hline Sales (Millions RMB) & 705.70 & 423.24 & 924.81 & 1,056 \\
\hline Total employees & $2,702.06$ & $1,826.50$ & $3,094.26$ & 652 \\
\hline State Ownership (\%) & 26.03 & 26.46 & 22.19 & 1,059 \\
\hline Legal Person Ownership (\%) & 29.12 & 25.47 & 21.78 & 1,059 \\
\hline Debt-to-Equity & 0.20 & 0.08 & 0.68 & 1,040 \\
\hline Firm Age at IPO (year) & 4.65 & 4.00 & 2.04 & 189 \\
\hline \multicolumn{5}{|l|}{ Non-ESOP firms } \\
\hline Asset (Millions RMB) & $1,335.33$ & 970.75 & $1,396.42$ & 1,060 \\
\hline Sales (Millions RMB) & 771.97 & 436.60 & $1,193.18$ & 1,060 \\
\hline Total employees & $2,433.97$ & $1,903.50$ & $2,164.39$ & 638 \\
\hline State Ownership (\%) & 33.53 & 36.12 & 29.20 & 1,060 \\
\hline Legal Person Ownership (\%) & 30.97 & 24.35 & 28.17 & 1,060 \\
\hline Debt-to-Equity & 0.15 & 0.05 & 0.38 & 1,040 \\
\hline Firm Age at IPO (year) & 2.30 & 1.00 & 3.08 & 189 \\
\hline
\end{tabular}




\section{Table 5. Pattern of Tradable Shares: ESOP Firms vs. Non-ESOP Firms}

This table compares percentage changes in the number of total tradable shares between ESOP and non-ESOP firms in the first six years after listing. The total sample consists of all 750 firms listed on Shanghai and Shenzhen Stock Exchanges from January 1996 to December 2000. The matched sample consists of 189 pairs of ESOP and nonESOP firms that are matched by size, industry, and listing year. The $t$-statistic is reported for the difference in the percentage change between ESOP firms and non-ESOP firms. ${ }^{*}, * *$, and $* * *$ indicate statistical significance at the $10 \%, 5 \%$, and $1 \%$ level, respectively.

\begin{tabular}{cccccc}
\hline & ESOP firms & $\begin{array}{c}\text { Non-ESOP } \\
\text { firms }\end{array}$ & Difference & $\begin{array}{c}t \text {-statistic for } \\
\text { difference }\end{array}$ & Observation \\
\hline IPO year & $15.24 \%$ & \multicolumn{2}{c}{ A. Total sample } & & \\
Year 2 & $31.48 \%$ & $30.79 \%$ & $0.90 \%$ & 0.41 & 749 \\
Year 3 & $34.47 \%$ & $19.87 \%$ & $14.60 \% * * *$ & 0.23 & 749 \\
Year 4 & $69.88 \%$ & $15.79 \%$ & $54.09 \% * * *$ & 16.96 & 750 \\
Year 5 & $12.37 \%$ & $15.46 \%$ & $-3.09 \%$ & -0.87 & 612 \\
Year 6 & $11.65 \%$ & $12.42 \%$ & $-0.77 \%$ & -0.29 & 514 \\
& & & & \\
IPO year & $14.37 \%$ & $17.21 \%$ & $-2.84 \%$ & -0.92 & 378 \\
Year 2 & $28.66 \%$ & $35.08 \%$ & $-6.42 \%$ & -1.58 & 378 \\
Year 3 & $37.78 \%$ & $20.90 \%$ & $16.88 \% * * *$ & 3.54 & 378 \\
Year 4 & $69.31 \%$ & $12.74 \%$ & $56.57 \% * * *$ & 12.47 & 377 \\
Year 5 & $13.79 \%$ & $19.96 \%$ & $-6.17 \%$ & -1.11 & 325 \\
Year 6 & $10.29 \%$ & $15.21 \%$ & $-4.92 \%$ & -1.44 & 282 \\
\hline
\end{tabular}




\section{Table 6. Base Regressions of Firm Performance}

This table presents the regressions of four performance measures, return on assets (ROA), return on equity (ROE), return on sales (ROS), and Tobin's q, for both the total sample and the matched sample. The total sample consists of all 750 firms listed on Shanghai and Shenzhen Stock Exchanges from January 1996 to December 2000. The matched sample consists of 189 pairs of ESOP and non-ESOP firms that are matched by size, industry, and listing year. ESOP is a dummy variable that takes the value of one if a firm adopts an ESOP, and zero otherwise. The $t$-statistics are reported in parentheses. ${ }^{*}, * *$, and ${ }^{* * *}$ indicate statistical significance at the $10 \%, 5 \%$, and $1 \%$ level, respectively.

\begin{tabular}{|c|c|c|c|c|c|c|c|c|}
\hline \multirow{2}{*}{ Independent Variables } & \multicolumn{4}{|c|}{ (Total sample) } & \multicolumn{4}{|c|}{ (Matched sample) } \\
\hline & $\mathrm{ROA}$ & ROE & ROS & Tobin's q & $\mathrm{ROA}$ & ROE & ROS & Tobin's q \\
\hline ESOP & $\begin{array}{l}0.14 \\
(0.80)\end{array}$ & $\begin{array}{l}0.13 \\
(0.31)\end{array}$ & $\begin{array}{l}1.35^{*} \\
(1.84)\end{array}$ & $\begin{array}{l}-0.03 \\
(-0.72)\end{array}$ & $\begin{array}{l}0.25 \\
(1.01)\end{array}$ & $\begin{array}{l}0.07 \\
(0.11)\end{array}$ & $\begin{array}{l}0.33 \\
(0.30)\end{array}$ & $\begin{array}{l}-0.04 \\
(-0.71)\end{array}$ \\
\hline $\ln$ (Total asset) & $\begin{array}{l}0.42 * * * \\
(4.26)\end{array}$ & $\begin{array}{l}1.85 * * * \\
(8.20)\end{array}$ & $\begin{array}{l}0.98 * * \\
(2.44)\end{array}$ & $\begin{array}{l}-0.88 * * * \\
(-40.44)\end{array}$ & $\begin{array}{l}0.26 \\
(1.61)\end{array}$ & $\begin{array}{l}2.20 * * * \\
(5.00)\end{array}$ & $\begin{array}{l}1.98 * * * \\
(2.71)\end{array}$ & $\begin{array}{l}-0.97 * * * \\
(-28.68)\end{array}$ \\
\hline Debt-to-equity ratio & $\begin{array}{l}-1.44 * * * \\
(-9.36)\end{array}$ & $\begin{array}{l}-1.74 * * * \\
(-3.62)\end{array}$ & $\begin{array}{l}-4.91 * * * \\
(-7.77)\end{array}$ & $\begin{array}{l}-0.10 * * * \\
(-2.90)\end{array}$ & $\begin{array}{l}-1.70 * * * \\
(-8.62)\end{array}$ & $\begin{array}{l}-2.88 * * * \\
(-3.59)\end{array}$ & $\begin{array}{l}-7.44 * * * \\
(-7.77)\end{array}$ & $\begin{array}{l}-0.15^{* * *} \\
(-3.17)\end{array}$ \\
\hline State shares $(\%)$ & $\begin{array}{l}0.03 * * * \\
(3.57)\end{array}$ & $\begin{array}{l}0.04 * * \\
(2.39)\end{array}$ & $\begin{array}{l}0.04 \\
(1.27)\end{array}$ & $\begin{array}{l}0.01 * * * \\
(6.61)\end{array}$ & $\begin{array}{l}0.01 \\
(1.17)\end{array}$ & $\begin{array}{l}0.01 \\
(0.38)\end{array}$ & $\begin{array}{l}-0.06 \\
(-1.13)\end{array}$ & $\begin{array}{l}0.01 * * * \\
(3.85)\end{array}$ \\
\hline Legal person shares $(\%)$ & $\begin{array}{l}0.03 * * * \\
(3.71)\end{array}$ & $\begin{array}{l}0.05 * * * \\
(2.63)\end{array}$ & $\begin{array}{l}0.04 \\
(1.31)\end{array}$ & $\begin{array}{l}0.01 * * * \\
(8.38)\end{array}$ & $\begin{array}{l}0.02 * \\
(1.88)\end{array}$ & $\begin{array}{l}0.03 \\
(0.91)\end{array}$ & $\begin{array}{l}-0.04 \\
(-0.79)\end{array}$ & $\begin{array}{l}0.01 * * * \\
(5.14)\end{array}$ \\
\hline Firm age & $\begin{array}{l}-0.12 * * * \\
(-5.56)\end{array}$ & $\begin{array}{l}-0.12 * * \\
(-2.54)\end{array}$ & $\begin{array}{l}-0.48 * * * \\
(-5.51)\end{array}$ & $\begin{array}{l}-0.02 * * * \\
(-3.66)\end{array}$ & $\begin{array}{l}-0.18 * * * \\
(-4.31)\end{array}$ & $\begin{array}{l}-0.23 * * \\
(-2.05)\end{array}$ & $\begin{array}{l}-0.70 * * * \\
(-3.73)\end{array}$ & $\begin{array}{l}-0.01 \\
(-1.47)\end{array}$ \\
\hline Intercept & $\begin{array}{l}3.77 * * * \\
(4.39)\end{array}$ & $\begin{array}{l}-0.53 \\
(-0.27)\end{array}$ & $\begin{array}{l}10.17^{* * *} \\
(2.90)\end{array}$ & $\begin{array}{l}7.65 * * * \\
(40.40)\end{array}$ & $\begin{array}{l}5.57 * * * \\
(4.02)\end{array}$ & $\begin{array}{l}-0.32 \\
(-0.09)\end{array}$ & $\begin{array}{l}9.26 \\
(1.50)\end{array}$ & $\begin{array}{l}8.37 * * * \\
(29.64)\end{array}$ \\
\hline Exchange dummy & Yes & Yes & Yes & Yes & Yes & Yes & Yes & Yes \\
\hline Industry effects & Yes & Yes & Yes & Yes & Yes & Yes & Yes & Yes \\
\hline Year effects & Yes & Yes & Yes & Yes & Yes & Yes & Yes & Yes \\
\hline Adjusted R-squared & 0.19 & 0.12 & 0.14 & 0.48 & 0.18 & 0.09 & 0.13 & 0.45 \\
\hline Observation & 3,981 & 3,983 & 3,972 & 3,978 & 2,036 & 2,038 & 2,032 & 2,038 \\
\hline
\end{tabular}




\section{Table 7. By-Year Regressions of Firm Performance}

This table reports the regressions of four performance measures, ROA, ROE, ROS, and Tobin's q, separately for each of the six years after listing. The model specifications are the same as those in Table 6. For each regression, we only report the coefficient on the ESOP dummy. The $t$-statistics are reported in parentheses. * ${ }^{* *}$, and $* *$ indicate statistical significance at the $10 \%, 5 \%$, and $1 \%$ level, respectively.

\begin{tabular}{|c|c|c|c|c|c|c|c|c|c|c|c|c|}
\hline & \multicolumn{6}{|c|}{ (Total sample) } & \multicolumn{6}{|c|}{ (Matched sample) } \\
\hline & IPO year & Year 2 & Year 3 & Year 4 & Year 5 & Year 6 & IPO year & Year 2 & Year 3 & Year 4 & Year 5 & Year 6 \\
\hline \multicolumn{13}{|l|}{ ROA: } \\
\hline ESOP dummy & -0.19 & 0.25 & 0.12 & 0.24 & 0.57 & 0.44 & -0.10 & 0.01 & 0.31 & 0.64 & -0.44 & 0.06 \\
\hline$t$-statistic & $(-0.77)$ & $(0.66)$ & $(0.26)$ & $(0.51)$ & $(1.15)$ & $(0.80)$ & $(-0.28)$ & $(0.02)$ & $(0.49)$ & $(1.02)$ & $(-0.61)$ & $(0.08)$ \\
\hline Observation & 733 & 719 & 718 & 722 & 591 & 498 & 371 & 358 & 360 & 360 & 314 & 273 \\
\hline \multicolumn{13}{|l|}{ ROE: } \\
\hline ESOP dummy & $-0.99 * * *$ & -0.19 & 0.15 & -0.17 & 1.33 & 1.56 & $-1.06^{*}$ & -1.03 & 1.31 & 1.09 & -0.26 & -0.88 \\
\hline$t$-statistic & $(-2.62)$ & $(-0.27)$ & $(0.14)$ & $(-0.15)$ & $(1.02)$ & $(1.18)$ & $(-1.87)$ & $(-0.92)$ & $(0.78)$ & $(0.56)$ & $(-0.14)$ & $(-0.42)$ \\
\hline Observation & 737 & 724 & 722 & 719 & 590 & 491 & 373 & 361 & 361 & 360 & 313 & 270 \\
\hline \multicolumn{13}{|l|}{ ROS: } \\
\hline ESOP dummy & 0.08 & 0.90 & $2.95^{*}$ & 2.47 & 1.32 & 1.47 & 0.16 & 0.58 & 1.13 & 2.31 & -2.89 & -4.52 \\
\hline$t$-statistic & $(0.08)$ & $(0.63)$ & $(1.79)$ & $(1.22)$ & $(0.67)$ & $(0.54)$ & $(0.12)$ & $(0.24)$ & $(0.39)$ & $(0.86)$ & $(-1.02)$ & $(-1.24)$ \\
\hline Observation & 731 & 720 & 718 & 719 & 589 & 495 & 371 & 363 & 360 & 357 & 310 & 271 \\
\hline \multicolumn{13}{|l|}{ Tobin's Q: } \\
\hline ESOP dummy & $-0.17 *$ & 0.11 & 0.06 & 0.02 & -0.12 & -0.01 & -0.12 & 0.05 & 0.06 & 0.07 & -0.18 & -0.13 \\
\hline$t$-statistic & $(-1.79)$ & $(1.05)$ & $(0.66)$ & $(0.18)$ & $(-1.27)$ & $(-0.06)$ & $(-1.07)$ & $(0.36)$ & $(0.45)$ & $(0.66)$ & $(-1.50)$ & $(-0.94)$ \\
\hline Observation & 735 & 728 & 721 & 713 & 584 & 497 & 374 & 365 & 364 & 357 & 308 & 270 \\
\hline
\end{tabular}




\section{Table 8. Production Function Regressions}

This table presents the regressions of firm production for the total sample and the matched sample. The total sample consists of all 750 firms listed on Shanghai and Shenzhen Stock Exchanges from January 1996 to December 2000. The matched sample consists of 189 pairs of ESOP and non-ESOP firms that are matched by size, industry, and listing year. The data on labor are available starting in 1999, so the regressions in this table are run for the period of 1999-2003. We define output as value added, which we measure by total sales minus direct operating costs. ESOP is a dummy variable that takes the value of one if a firm adopts an ESOP, and zero otherwise. Control variables include debt-to-equity ratio, state shares, legal-person shares, and firm age, for which the coefficients are not reported. The $t$-statistics are reported in parentheses. ${ }^{*}, *$, and $* * *$ indicate statistical significance at the $10 \%, 5 \%$, and $1 \%$ level, respectively.

\begin{tabular}{|c|c|c|c|c|}
\hline \multirow{3}{*}{ Independent variables } & \multicolumn{4}{|c|}{ Dependent variable: $\ln ($ Output $)$} \\
\hline & \multicolumn{2}{|c|}{ (Total sample) } & \multicolumn{2}{|c|}{ (Matched sample) } \\
\hline & Cobb-Douglas & Translog & Cobb-Douglas & Translog \\
\hline ESOP & $\begin{array}{l}-0.02 \\
(-0.60)\end{array}$ & $\begin{array}{l}-0.02 \\
(-0.64)\end{array}$ & $\begin{array}{l}-0.04 \\
(-0.88)\end{array}$ & $\begin{array}{l}-0.03 \\
(-0.78)\end{array}$ \\
\hline $\ln ($ Capital) & $\begin{array}{l}1.02 * * * \\
(53.04)\end{array}$ & $\begin{array}{l}1.13^{* * *} \\
(6.32)\end{array}$ & $\begin{array}{l}1.03 * * * \\
(32.65)\end{array}$ & $\begin{array}{l}0.59^{*} \\
(1.66)\end{array}$ \\
\hline $\ln ($ Labor $)$ & $\begin{array}{l}0.11^{* * *} \\
(7.26)\end{array}$ & $\begin{array}{l}-0.17 \\
(-1.37)\end{array}$ & $\begin{array}{l}0.10^{* * *} \\
(3.88)\end{array}$ & $\begin{array}{l}0.28 \\
(1.25)\end{array}$ \\
\hline $\ln ($ Capital $) \times \ln ($ Capital $)$ & & $\begin{array}{l}-0.04 * * \\
(-2.12)\end{array}$ & & $\begin{array}{l}0.04 \\
(1.16)\end{array}$ \\
\hline $\ln ($ Labor $) \times \ln ($ Labor $)$ & & $\begin{array}{l}-0.007 \\
(-0.78)\end{array}$ & & $\begin{array}{l}-0.01 \\
(-0.50)\end{array}$ \\
\hline $\ln ($ Capital $) \times \ln ($ Labor $)$ & & $\begin{array}{l}0.05^{* * *} \\
(2.63)\end{array}$ & & $\begin{array}{l}-0.01 \\
(-0.20)\end{array}$ \\
\hline Intercept & $\begin{array}{l}-3.26^{* * *} \\
(-21.92)\end{array}$ & $\begin{array}{l}-2.64 * * * \\
(-3.73)\end{array}$ & $\begin{array}{l}-3.29 * * * \\
(-12.06)\end{array}$ & $\begin{array}{l}-2.36^{*} \\
(-1.7)\end{array}$ \\
\hline Control variables & Yes & Yes & Yes & Yes \\
\hline Exchange Dummy & Yes & Yes & Yes & Yes \\
\hline Industry effects & Yes & Yes & Yes & Yes \\
\hline Year effects & Yes & Yes & Yes & Yes \\
\hline Adjusted R-squared & 0.68 & 0.68 & 0.61 & 0.61 \\
\hline Observation & 2,585 & 2,585 & 1,251 & 1,251 \\
\hline
\end{tabular}




\section{Table 9. IPO Pricing: ESOP Stocks vs. Non-ESOP Stocks}

This table presents the comparison of stock value in the IPO year between ESOP and non-ESOP firms. The total sample consists of all 750 firms listed on Shanghai and Shenzhen Stock Exchanges from January 1996 to December 2000. The matched sample consists of 189 pairs of ESOP and non-ESOP firms matched by size (firm sales), industry, and listing year. We calculate the market value for total tradable shares at the stock's first-day closing price. The $t$-statistics are reported for differences between ESOP firms and non-ESOP firms. *,**, and $* * *$ indicate statistical significance at the $10 \%, 5 \%$, and $1 \%$ level, respectively.

\begin{tabular}{|c|c|c|c|c|c|}
\hline Variables & ESOPs & $\begin{array}{l}\text { Non- } \\
\text { ESOPs }\end{array}$ & Difference & $\begin{array}{l}\text { t-statistic } \\
\text { for } \\
\text { difference }\end{array}$ & Observation \\
\hline \multicolumn{6}{|c|}{ A: Total sample } \\
\hline First-day closing price (RMB) & 14.58 & 14.98 & -0.41 & -0.82 & 735 \\
\hline MV at the first-day closing (million RMB) & 529.55 & 698.98 & $-169.43 * * *$ & -5.33 & 735 \\
\hline IPO offer price (RMB) & 6.24 & 5.80 & $0.44 * *$ & 2.36 & 735 \\
\hline IPO initial return (\%) & 159.05 & 245.38 & $-86.32 * * *$ & -3.45 & 735 \\
\hline \multicolumn{6}{|c|}{ B. Matched sample } \\
\hline First-day closing price (RMB) & 14.55 & 14.34 & 0.21 & 0.37 & 371 \\
\hline MV at the first-day closing (million RMB) & 538.03 & 578.59 & -40.56 & -1.20 & 371 \\
\hline IPO offer price (RMB) & 6.27 & 5.34 & $0.93 * * *$ & 3.81 & 371 \\
\hline IPO initial return (\%) & 154.47 & 307.31 & $-152.84 * * *$ & -4.28 & 371 \\
\hline
\end{tabular}

